\title{
Nauczyciel wobec otwartości uczniów w przestrzeni edukacyinej
}

\author{
The Teacher in Regard to the Openness \\ of the Students in the Educational Space
}

\begin{abstract}
ABSTRAKT
Szkoła stanowi ważna przestrzeń oddziaływująca na nabywanie doświadczeń przez uczniów. Przestrzeń ta jest kształtowana przez nauczycieli-profesjonalistów. Podejmują oni działania majqce na celu stworzenie przyjaznego miejsca, w którym znaczqca rolę odgrywaiq relacje interpersonalne. W prawidłowych kontaktach nauczyciela z uczniami ważna jest otwartość. Polega ona na naturalnej wymianie informacji pomiędzy rozmówcami w codziennych relacjach. Umożliwia lepsze wzajemne poznanie poprzez odkrywanie nowych obszarów komunikowania się. Cechami otwartości sq dwustronność i wzajemność. Dostrzegajqc znaczenie otwartości w kształtowaniu przestrzeni edukacyinej, podięto badania nad postrzeganiem przez przyszłych nauczycieli problematyki otwartości w stosunku do ucznia. Badania przeprowadzono wśród studentów studiów stacjonarnych UMCS w Lublinie z dwóch kierunków: anglistyki i matematyki. Wyniki badań zamieszczone w artykule wskazuja, że przyszli nauczyciele w większości prawidłowo rozumiejq istotę otwartości. Zauwa-


żaja jej wartość w relacjach z innymi nauczycielami, uczniem i klasq. Maja problemy z powstrzymywaniem się od oceniania i dawania rad podczas przekazywania informacji. Zwłaszcza koncentrowanie się na treściach dotyczących konkretnych zachowań sprawia im trudność. Pozytywny aspekt jest taki, że studenci zwracajq uwagę na rolę komunikatów niewerbalnych. Przyszli matematycy znacznie częściej podkreślali, że właściwe postępowanie nauczyciela może się przyczyniać do kształtowania otwartości uczniów, gdyż w przeciwnym razie uczniowie moga doświadczać blokady przed nawiq̨zaniem kontaktu. Studenci sq świadomi, że poszerzanie własnej otwartości sprzyja ich rozwojowi i wzbogaca relacje z uczniami.

\section{ABSTRACT}

The school is an important space, acting on acquiring experience for students and it is shaped by professional teachers. They attempt to create a friendly place, where a significant role is played by interpersonal relationships. In normal contacts between the teacher and the students, the aspect of openness is very important. It is based on the natural exchange of information between the interlocutors in everyday relations. It allows them to discover new areas of communication. The features of openness are bilateral and reciprocity. Recognizing the importance of openness in the shaping of the educational space, research has been made on the perception of future teachers in terms of the issue of openness in relation to the student. The study was attended by students of UMCS in Lublin from two faculties: English and mathematics. The results of the research presented in the article show that future teachers largely understand the importance of openness. They notice its value in relationships with other teachers, students and the class community. They have problems in refraining from judging and giving advice when transferring information. The most difficult part for them is focusing on content related to specific behaviors. The positive aspect is that the students pay attention to the role of non-verbal communication. Future mathematicians more frequently emphasized that the proper conduct of the teacher can help to shape the openness of the students, because otherwise they may have difficulty in fostering contacts. Students are aware that the extension of their own openness is positive in terms of their development and enriches relationships with students. 


\section{Wprowadzenie}

Przestrzeń jest kategorią, w kontekście której należy rozpatrywać relacje nauczyciela z uczniami. Odwołując się do rozważań Floriana Znanieckiego, przestrzeń można ująć w znaczeniu fizycznym, geometrycznym i społecznym ${ }^{1}$. Rozumienie przestrzeni w wymiarze społecznym ma istotne znaczenie dla analizy kwestii związanych z edukacją. Humanistyczne podejście Yi-Fu Tuana ${ }^{2}$ zakłada, że dopiero to jednostka zamienia przestrzeń w miejsce i nadaje jej znaczenie. W sytuacjach szkolnych uczniowie przebywając i ucząc się w szkole odczuwają kreacyjną rolę przestrzeni, a jednocześnie wraz z nauczycielami kształtują przestrzeń publiczną (np. korytarz, sala lekcyjna) i prywatną (np. szatnia, toaleta), zapewniającą uczniom intymność i poczucie bezpieczeństwa w upatrzonym przez siebie miejscu, zakamarku³. Pedagogiczna przestrzeń, w której przebiega życie szkolne, może się stać zadomowiona, oswojona i własna, stanowiąc przyjazne miejsce wtedy, gdy relacje będą w niej oparte na wzajemnej otwartości. Sposób aranżacji przestrzeni w budynku szkolnym warunkuje przebieg komunikacji i określa rodzaj indywidualnych doświadczeń gromadzonych przez uczniów ${ }^{4}$.

Obecnie spotykamy wiele sytuacji, w których ludzie przejawiają otwartość, coraz częściej podkreślana jest także potrzeba otwartości w różnych sytuacjach społecznych. Rozwiązywanie złożonych problemów i funkcjonowanie w różnych kontekstach społecznych oraz adaptacja jednostki do dynamicznie zmieniającej się rzeczywistości wymagają od ludzi otwartej postawy w codziennych relacjach. Otwartość jest charakterystyczną dla jednostki właściwością, która może być kształtowana w procesie dydaktyczno-wychowawczym. Jest elementem uzupełniającym poczucie integracji i identyfikacji człowieka ${ }^{5}$, a zarazem jego tożsamości. Rolę otwartości powinni dostrzegać nauczyciele, którzy w częstych i bezpośrednich kontaktach z uczniami mogą się przyczynić do jej kształtowania u uczniów, mając świadomość, że jej brak

1 Za: A. Nalaskowski, Przestrzenie i miejsca szkoty, Kraków 2002, s. 10.

2 Y.-F. Tuan, Przestrzeń i miejsce, przeł. A. Morawińska, Warszawa 1987.

3 Za: A. Nalaskowski, Przestrzenie i miejsca szkoty, dz. cyt., s. 58-60.

4 M. Mendel, Przekraczanie progu szkoty jako „rite de passage”, w: Pedagogika miejsca, red. M. Mendel, Wrocław 2006, s. 181.

5 M. Wolicki, Otwartośc osoby ludzkiej. Interpretacja filozoficzna, Wrocław 2005, s. 23. 
może prowadzić do poczucia osamotnienia, konfliktów interpersonalnych, a nawet izolacji w grupie. Warto podkreślić, że nawet wówczas kiedy nauczyciele działają rutynowo i powtarzalnie, będąc autorami procesu kształcenia budują wielowymiarowe interakcje wynikające z dynamiki sytuacji w przestrzeniach szkoły.

\section{Profesjonalizm nauczyciela w procesie nauczania i wychowania}

Od współczesnych nauczycieli oczekuje się, by byli skuteczni w prowadzonych działaniach i troszczyli się o to, aby ich uczniowie odnosili sukcesy oraz kształtowali spójną tożsamość. Działania takie można odnieść do różnych przestrzeni i środowisk wychowawczych, wśród których wskazuje się klasę, szkołę, grupę rówieśniczą oraz do towarzyszących im procesów, np. ukierunkowywania na kontakty z kulturą (popularną, wysoką) czy z innymi ludźmi. Profesjonalizm wiąże się z autorytetem intelektualnym, dokonywaniem racjonalnych osądów i podejmowaniem skutecznych działań. Rozważając problematykę profesjonalizmu nauczycieli, Bogusława D. Gołębniak ${ }^{6}$ eksponuje humanistyczny wymiar ich funkcjonowania oraz podkreśla znaczenie etycznego aspektu w wypełnianiu roli, podlegającej ciągłej kontroli, związanej z zachowaniem bezstronności oraz umiejętności rozpoznawania i rozumienia potrzeb uczniów, co w perspektywie powinno prowadzić do budowania kapitału społecznego. Henryka Kwiatkowska ${ }^{7}$ zwraca uwagę, że profesjonalizm nauczyciela wiąże się z wysokimi standardami poznawczymi, działaniowymi i etycznymi oraz samodzielnym badaniem, refleksyjnością i doskonaleniem pracy w konkretnych sytuacjach i niestandardowych przypadkach, na podstawie których budowana jest osobista wiedza nauczyciela wkomponowana w wiedzę akademicką, co warunkuje działania „profesjonalne”, optymalne.

Nauczyciel-profesjonalista powinien pomagać uczniom w dążeniu do samopoznania i samoakceptacji oraz rozumienia motywów własnych zachowań w kontaktach z innymi i percepcji otaczającej przestrzeni. Niezbędne są przy tym kompetencje techniczne, od których zależy instrumentalnie rozumiana sprawność działania. Można wyodrębnić kompetencje postulacyjne, metodyczne i realizacyjne.

6 B.D. Gołębniak, Nabywanie kompetencji do refleksyjnego nauczania, w: Uczenie metoda projektów, red. B.D. Gołębniak, Warszawa 2002, s. 12-13.

7 H. Kwiatkowska, Pedeutologia, Warszawa 2008, s. 167-168. 
Kompetencje postulacyjne (normatywne) należy rozumieć jako umiejętność sprawczych oddziaływań oraz wskazywanie kierunków i płaszczyzn osiągania celów podejmowanych przez jednostkę. W praktyce edukacyjnej cele te odnoszą się do poszczególnych przedmiotów nauczania. Kompetencje metodyczne umożliwiają wykorzystywanie na lekcji różnych sposobów nauczania. Na początku odbywa się to w sposób odtwórczy na zasadzie naśladownictwa i przestrzegania reguł, a z czasem wypracowywane są przez nauczyciela własne (kreatywne) pomysły na pracę dydaktyczną. Osoba posiadająca kompetencje realizacyjne tworzy środowisko sprzyjające nauczaniu. Wiąże się to z odpowiednim doborem środków dydaktycznych, ułatwiających osiąganie zakładanych celów. Nauczyciel dostrzegający znaczenie kompetencji zawodowych stara się doskonalić własną pracę poprzez ciągłe poszukiwanie nowych metod przekazywania treści z wykorzystaniem nowatorskich środków dydaktycznych i poszerzaniem repertuaru skutecznych sposobów działań edukacyjnych.

Skuteczny nauczyciel to osoba legitymizująca się umiejętnościami praktyczno-moralnymi, które obejmują trzy obszary. Pierwszy to kompetencje interpretacyjne, które wiążą się z całościowym postrzeganiem świata i siebie samych, a także jego rozumieniem i nadawaniem sensu dziejącym się w rzeczywistości zjawiskom i zdarzeniom. Kolejny to kompetencje moralne, które określają reguły wskazywania sensu, wyznaczają zasady moralne oraz pozwalają na snucie refleksji moralnych wobec postępowania własnego (autorefleksja) i innych. Refleksje moralne dotyczą tego, jak dochować wierności sobie i jak nie ograniczać innym praw do decydowania o postępowaniu, zwłaszcza w kontekście oddziaływania mediów. Trzeci obszar stanowią kompetencje komunikacyjne, umożliwiające porozumiewanie się z innymi, bycie $\mathrm{z}$ nimi w rzeczywistym dialogu opartym na wymianie osobistych opinii. W budowaniu autentycznego dialogu oznaczającego znoszenie blokad komunikacyjnych, które wynikałyby ze stereotypowo spostrzeganych stosunków zależności nauczyciel-uczeń, znaczącą rolę odgrywa otwartość ${ }^{8}$ sprzyjająca oswojeniu przestrzeni szkolnej, w której uczeń zaspokaja swoje potrzeby.

8 R. Kwaśnica, Dwie racjonalności. Od filozofii sensu ku pedagogice ogólnej, Wroclaw 2007, s. 72-79; R. Kwaśnica, Wprowadzenie do myślenia o nauczycielu, w: Pedagogika podręcznik akademicki, red. Z. Kwieciński, B. Śliwerski, Warszawa 2006, s. 298-301. 


\section{Otwartość jako kategoria pedagogiczna}

Otwartość w literaturze jest charakteryzowana jako zdolność komunikacji poznawczej z otaczającym światem poprzez transformacje wiedzy i poszukiwanie sensu istnienia, a także jako wymiana informacji z innymi ludźmi na temat myśli, pojawiających się odczuć, własnych doświadczeń. Odkrywanie siebie przed innymi pomaga nam lepiej zrozumieć i zasymilować własne przeżycia, refleksje, interpretacje zdarzeń, co przyczynia się do wzmocnienia więzi interpersonalnych i sygnalizuje przywiązanie do osób, z którymi dzielimy się własną wiedzą i doświadczeniem. Otwartość jest zawsze dwustronna, co oznacza dawanie i przyjmowanie informacji od innych. Występują różnice indywidualne w poziomie otwartości, wynikające z podatności jednostki na oddziaływania zewnętrzne, w tym rodzaj wpływu i sposób jego odbierania. W praktyce wychowawczej oznacza to, że niektórzy uczniowie moga być bardziej otwarci, a inni wręcz zamknięci na dany rodzaj wpływów.

Otwarcie można wiązać $\mathrm{z}$ odsłanianiem się, odkrywaniem siebie przed innymi, rozumianym jako pokazywanie swojego prawdziwego $\mathrm{Ja}^{10}$. Osobiste, głębokie otwarcie przed innymi ludźmi warunkowane jest komunikacją werbalnąa ${ }^{11}$ W kontaktach międzyludzkich dostrzegamy przechodzenie od wymiany powierzchownych informacji, które wzbogacane są komunikatami niewerbalnymi, do bardziej osobistych, co najczęściej musi być związane ze wzajemną otwartością. Ujawnianie własnych doświadczeń wiąże się z oczekiwaniem, że rozmówca także będzie autentyczny i skłonny do odkrywania siebie. Otworzyć się można zatem przed kimś, ujawniając swoje prawdziwe Ja bądź też na kogoś, gdy jesteśmy gotowi go wysłuchać z zainteresowaniem, życzliwością, przychylnym nastawieniem, prawdziwym zrozumieniem i akceptacją. Wielość znaczeń i interpretacji otwartości podkreśla pozytywne jej aspekty, pozbawione negatywnych konotacji, powodujących urazy, smutek, żal czy cierpienie.

Jeśli otwartość polega na naturalnej, niewymuszonej wymianie osobistych informacji między osobami będącymi w codziennych

9 M. Wolicki, Otwartość osoby ludzkiej, dz. cyt., s. 25-26; L. Strumska-Cylwik, Pomiędzy otwartościq i zamknięciem, Kraków 2005, s. 41-45.

10 L. Strumska-Cylwik, Pomiędzy otwartościq i zamknięciem, dz. cyt., s. 27.

11 L. Niebrzydowski, E. Płaszczyński, Przyjaźń i otwartośc w stosunkach międzyludzkich, Warszawa 1989, s. 5-6. 
relacjach, możliwe jest lepsze wzajemne poznanie i odkrycie nowych obszarów komunikowania się i budowania przyjaznej przestrzeni. W interakcjach osoby chętniej otwierają się wobec tych, którzy odwzajemniają ich otwartość. Zakres otwartości związany jest z pełnionymi rolami społecznymi. Zazwyczaj ludzie gotowi są do ujawniania pozytywnych informacji o sobie, zwłaszcza na początku znajomości, ponieważ przekazywanie informacji negatywnych może zniechęcać do dalszych kontaktów. Dopiero bliższe wzajemne poznanie się przygotowuje do podejmowania trudnych tematów.

Spośród różnych ujęć można przyjąć rozumienie otwartości jako ujawnianie tego, jak reagujemy "na bieżącą sytuację i przekazywanie takich informacji z przeszłości, które są ważne dla zrozumienia" naszych obecnych reakcji wobec ludzi, wydarzeń, które nie należą do dziedziny faktów, ale do uczuć ${ }^{12}$.

W celu utrzymania otwartości w interakcji międzyosobowej konieczne jest konstruktywne przekazywanie informacji zwrotnych, czyli sposobów reagowania na zachowania innego człowieka. Trzeba się starać pomóc rzeczową informacją drugiej osobie w uzyskaniu wiedzy o tym, jak odczuwa i spostrzega jej funkcjonowanie. Jakość informacji zwrotnej zależy też od przesyłanych komunikatów niewerbalnych, wskazujących na aktywne słuchanie i właściwe rozumienie otrzymywanych informacji. Pewne fizyczne nastawienie do odbioru wiadomości sygnalizuje przyjmowana właściwa postawa ciała. Zasadniczą i ważną niewerbalną wskazówką jest utrzymywanie kontaktu wzrokowego, czyli zrównoważone patrzenie na rozmówcę, potwierdzające nasze zainteresowanie przekazywanymi komunikatami ${ }^{13}$.

Istotną rolę w relacjach społecznych pełni aktywne słuchanie, któremu towarzyszy empatia i związane $z$ nią poczucie bezpieczeństwa oraz okazywane drugiej osobie zaufanie, co jest podstawą właściwego sposobu przekazywania konstruktywnych informacji zwrotnych. Komunikaty nauczyciela mogą sprzyjać odpowiedniemu porozumiewaniu się z uczniami. Sposób przekazywania informacji zwrotnych musi być zaplanowany, przemyślany i bezpośredni, wyrażający szacunek wobec drugiej osoby uczestniczącej w interakcji. Zatem nauczyciel powinien zwracać uwagę, by przekazywane komunikaty miały charakter

12 D.W. Johnson, Podaj dton, przeł. B. Czarnecka, Warszawa 1992, s. 25.

13 L. Strumska-Cylwik, Pomiędzy otwartościq i zamknięciem, dz. cyt., s. 172-174. 
opisowy, czyli dostarczający potrzebnych wskazówek do działania, a nie koncentrowały się na ocenianiu postępowania. Przesyłane informacje mają dotyczyć tych zachowań, które uczeń powinien poprawić.

Właściwie wyrażane informacje winny być udzielane klarownie, w krótkim czasie i w odpowiednim miejscu. Nie należy stwarzać takich sytuacji, w których osoby uczestniczące w interakcji czułyby się zakłopotane czy zagrożone. Przestrzeń sprzyjająca komunikacji między nauczycielem a uczniem oznacza dobór i zagospodarowanie miejsca w taki sposób, aby uniknąć barier w nawiązywaniu dialogu. W celu zachowania intymności i swobody interakcji warto zadbać o udział w niej wyłącznie podmiotów zainteresowanych problemem. Informacje zwrotne powinny służyć niewymuszonemu, naturalnemu wsparciu danej osoby, czyli mają być użyteczne. Wypowiedzi dostarczające informacji powinny przybierać odpowiednią formę, zawierającą komunikaty ,ja”, wyrażone w sposób taktowny ${ }^{14}$.

Odebrane informacje mają dużą wartość szczególnie dla ucznia, który je otrzymuje od nauczyciela, gdyż w ten sposób dowiaduje się czegoś nowego na swój temat, zwłaszcza o przejawianych zachowaniach czy odczuwanych potrzebach. Bezpośrednie wyrażenie uczuć powoduje, że przekazywanie opinii jest szczere, co często zapobiega eskalacji uczuć negatywnych.

Jakość dialogu zależy od otwartości jednostki. Porozumiewanie się z klasą wiąże się z odkrywaniem siebie, co czasami oznacza ryzyko niewłaściwego rozumienia intencji wypowiedzi. W sytuacjach towarzyszących pracy dydaktycznej i wychowawczej dostrzec też można korzyści płynące z utrzymywania właściwej relacji z uczniami. Wśród postulowanych cech dobrego nauczyciela wymienia się jako jedną z pożądanych otwartość, która współwystępuje z empatią, przejawianą w różnorodnych zdarzeniach szkolnych. Otwartość wymaga akceptacji drugiej osoby, która ma często inny niż nauczyciel punkt widzenia i interpretowania zjawisk.

\section{Badania własne}

W relacjach nauczyciela $\mathrm{z}$ uczniami bardzo ważny jest sposób wzajemnego porozumiewania się. Doceniając wagę tego problemu, przedmiotem badań uczyniono postrzeganie przez nauczycieli

14 L. Strumska-Cylwik, Pomiędzy otwartościq i zamknięciem, dz. cyt., s. 172-173. 
znaczenia otwartości w procesie edukacji. Pod uwagę wzięto interakcje w praktyce szkolnej z uczniami i w gronie pedagogicznym.

Badania zostały przeprowadzone w roku akademickim 20015/2016 wśród studentów Uniwersytetu Marii Curie-Skłodowskiej w Lublinie przygotowujących się do pracy w zawodzie nauczyciela. Wszystkie badane osoby są absolwentami studiów licencjackich i posiadają kwalifikacje do pracy w szkole podstawowej (II etap edukacji). Odbyły praktyki pedagogiczne w szkołach w wymiarze 150 godzin. Wśród badanych było 57 studentów anglistyki i 54 studentów matematyki. W grupie badanych osób 79\% stanowiły kobiety, a 21\% mężczyźni. Średnia wieku studentów wyniosła 23 lata.

Materiał empiryczny gromadzono wykorzystując dwa narzędzia opracowane przez autorki. Pierwsze, uwzględniające wymiary otwartości wyodrębnione przez Davida W. Johnsona ${ }^{15}$, posłużyło do diagnozowania otwartości nauczycieli w różnych aspektach. Kolejne to kwestionariusz do oceny otwartości uczniów percypowanej przez przyszłych nauczycieli.

Zachowania związane z porozumiewaniem się warunkowane są konkretnymi sytuacjami, cechami jednostek, które w nich uczestniczą, a ponadto rozumieniem i interpretowaniem otwartości przez poszczególne osoby. Określanie otwartości przez studentów wobec podmiotów uczestniczących w edukacji przedstawiono w tabeli 1.

Tabela 1. Rozumienie pojęcia otwartość w relacjach interpersonalnych

\begin{tabular}{|c|c|c|c|c|c|c|c|c|c|c|c|c|c|}
\hline \multirow{3}{*}{\multicolumn{2}{|c|}{ Definiowanie otwartości }} & \multicolumn{4}{|c|}{ inni nauczyciele } & \multicolumn{4}{|c|}{ uczeń } & \multicolumn{4}{|c|}{ klasa } \\
\hline & & \multicolumn{2}{|c|}{ tak } & \multicolumn{2}{|c|}{ nie } & \multicolumn{2}{|c|}{ tak } & \multicolumn{2}{|c|}{ nie } & \multicolumn{2}{|c|}{ tak } & \multicolumn{2}{|c|}{ nie } \\
\hline & & $\mathrm{N}$ & $\%$ & $N$ & $\%$ & $N$ & $\%$ & $N$ & $\%$ & $\mathrm{~N}$ & $\%$ & $N$ & $\%$ \\
\hline $\begin{array}{l}\text { Otwartość } \\
\text { to ujawnienie, jak } \\
\text { reaguje } \\
\text { Pan/Pani na to, } \\
\text { co sie teraz dzieje }\end{array}$ & Grupa 1 & 27 & 47,37 & 30 & 52,63 & 38 & 66,67 & 19 & 33,33 & 33 & 57,89 & 24 & 42,11 \\
\hline $\begin{array}{l}\text { i przekazywanie } \\
\text { zwiqzanych z tym } \\
\text { tematem informacji } \\
\text { o przeszłości }\end{array}$ & Grupa 2 & 43 & 79,63 & 11 & 20,37 & 36 & 66,67 & 18 & 33,33 & 33 & 61,11 & 21 & 38,39 \\
\hline
\end{tabular}

15 D.W. Johnson, Podaj dtoń, dz. cyt. 


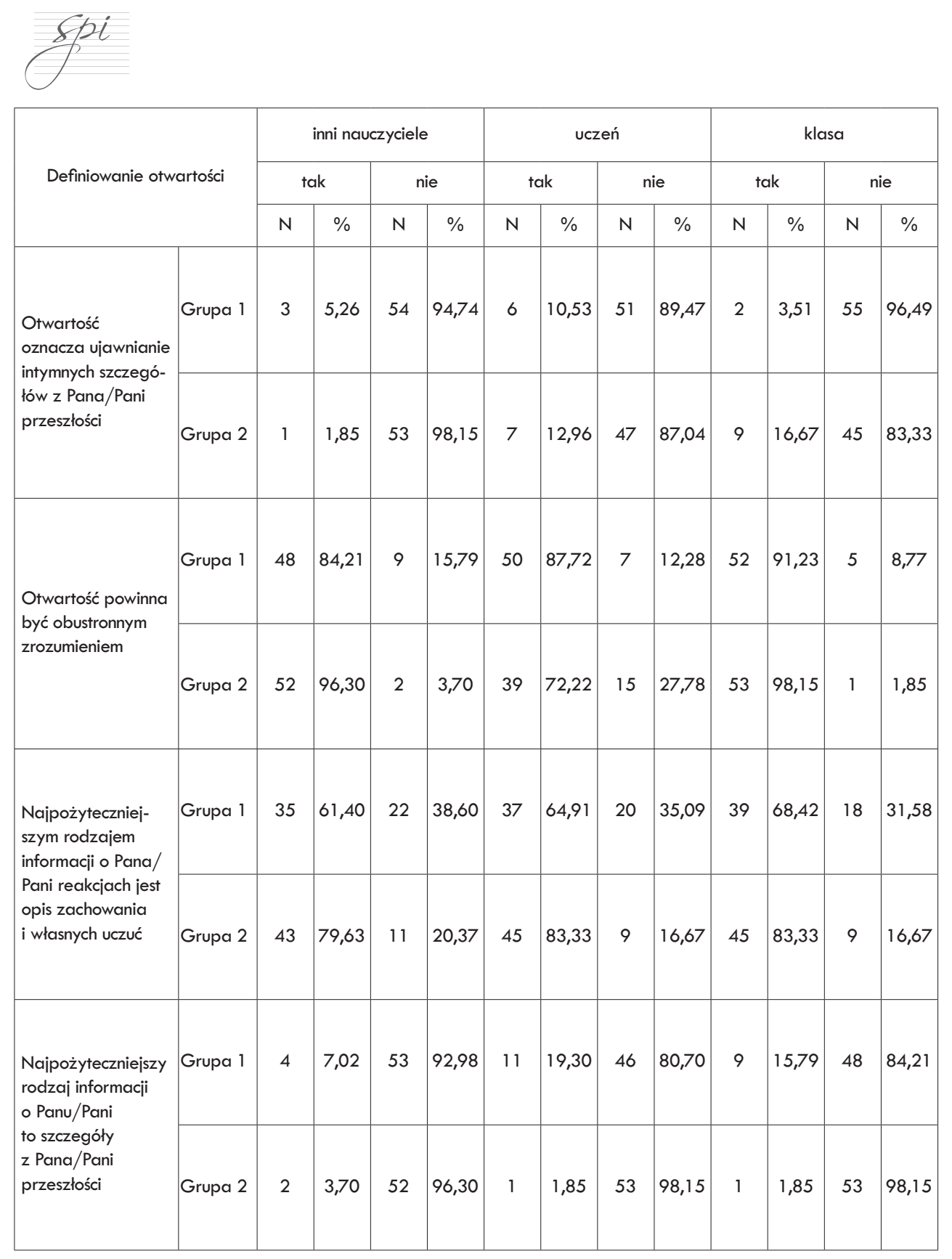

Źródło: badania własne Grupa 1 - studenci anglistyki Grupa 2 - studenci matematyki 
Otwartość sprzyja budowaniu znaczących relacji. Najwięcej poprawnych odpowiedzi udzielili przyszli nauczyciele języka angielskiego, wskazując, że otwartość powinna być obustronnym zrozumieniem. Tak odpowiedziało około $90 \%$ badanych, przy czym większość z nich wskazywała ten warunek poprawnej komunikacji wobec klasy. Przyszli nauczyciele matematyki udzielili więcej poprawnych odpowiedzi, jeszcze częściej właściwie ją rozumieli, jednak przede wszystkim w stosunku do innych nauczycieli i klasy, zaś w indywidualnym kontakcie $\mathrm{z}$ uczniem tylko niespełna trzy czwarte $\mathrm{z}$ nich opowiedziało się za obustronnym zrozumieniem. Jest to jednak powierzchowna interpretacja otwartości przez osoby z grupy pierwszej, ponieważ przy szczegółowym charakteryzowaniu relacji, zwłaszcza $\mathrm{z}$ innymi nauczycielami, wskazano trudności w przekazywaniu informacji związanych $\mathrm{z}$ określonym tematem $\mathrm{z}$ przeszłości. W grupie drugiej nie zauważono tej trudności w interpretacji, poza stosunkiem do innych nauczycieli.

Badani z obu grup w większości dostrzegali, że w relacjach nie jest konieczne przekazywanie informacji z przeszłości, w tym zwłaszcza informacji dotyczących życia prywatnego, co częściej dotyczyło grona pedagogicznego. Niemal wszyscy badani angliści nie wiązali przejawiania otwartości z ujawnianiem szczegółów z przeszłości, jednak częściej skłonni są to czynić w indywidualnych relacjach z uczniami. Korzystniej w poglądach na interakcje z uczniem i klasą wypadali przyszli matematycy. W najważniejszym aspekcie, związanym z opisem zachowania i własnych uczuć, sprzyjających tworzeniu odpowiednich relacji, ponad $60 \%$ przyszłych nauczycieli z grupy pierwszej i około $80 \%$ z grupy drugiej właściwie rozumiała istotę otwartości wobec ucznia i klasy, nieco mniej korzystnie interpretowała ją w stosunku do swoich kolegów.

Przyszli nauczyciele matematyki charakteryzując otwartość uczniów najczęściej łączyli ją z aktywnością na lekcji, np. odpowiadanie na pytania, chętne wykonywanie poleceń, ale także $\mathrm{z}$ realizacją nowych pomysłów, samorzutnym wyrażaniem własnych opinii. Sporadycznie podkreślali znaczenie kontaktów z kolegami i angażowanie się w projekty pozaszkolne. Wśród cech synonimicznych wymieniali, że uczniowie otwarci są mili i uprzejmi dla innych, potrafią mówić o swoich problemach. Studenci anglistyki zwracali uwagę głównie na pewność siebie, która pozwala podejmować nowe wyzwania oraz na 
dobre relacje wiążące się z tolerancją wobec innych, łącznie z chęcią niesienia im pomocy, na łatwość komunikowania się, a jedynie co piąty wiązał otwartość z pracą na lekcji. Niektórzy zwracali uwagę na gotowość do udziału w dodatkowych zajęciach rozwijających zainteresowania.

Oceniając otwartość uczniów, studenci zwrócili uwagę, że jej poziom należy łączyć $z$ wiekiem uczniów, specyficznymi cechami jednostki oraz z podmiotem interakcji. Badani zauważali, że uczniowie są bardziej otwarci w relacjach z kolegami. Jest to zgodne z wynikami innych badań, które pokazują, że ludzie są zazwyczaj bardziej otwarci wobec bliskich i przyjaciót16. Otwartość uczniów pozytywnie oceniała większość badanych, przy czym częściej czynili to przyszli nauczyciele matematyki, dostrzegając, że uczniowie osiągający gorsze wyniki w nauce są bardziej zamknięci. Niektórzy wskazywali, że mała otwartość może być powodowana, jak wypowiedziała się jedna z osób, „wpatrywaniem się w ekrany telefonów”. Zagrożeniem dla otwartości może być odrzucenie ucznia przez klasę. Na opinię studentów mogły mieć wpływ obserwacje dokonywane podczas wcześniejszych praktyk w szkołach. Jedna z osób zauważyła, że w klasach integracyjnych uczniowie są bardziej otwarci dzięki bezpośredniemu, codziennemu kontaktowi z uczniami o specjalnych potrzebach edukacyjnych.

Studenci zgodnie twierdzili, że otwartość ułatwia dialog uczniów z nauczycielem. Różnice dotyczą jednak obszaru pojawiających się korzyści. Przyszli nauczyciele matematyki zwracali uwagę, że otwartość uczniów ułatwia prowadzenie lekcji. Uczniowie nie boją się wówczas samodzielnego zadawania pytań, co zapewnia płynność lekcji i dialog w miejsce monologu nauczyciela. Sporadycznie podkreślali, że otwartość ułatwia rozwiązywanie konfliktów, dostrzeganie potrzeb, sprzyja poznawaniu uczniów. Studenci anglistyki eksponowali znaczenie otwartości w relacjach interpersonalnych. Ich zdaniem, pomaga ona w rozwiązywaniu problemów uczniów, w nawiązaniu współpracy, budowaniu więzi w klasie, pokonywaniu barier. Niektórzy podkreślali, że dzięki otwartości zmniejszana jest asymetryczność ról, co ułatwia wzajemny szacunek, pomaga w pokonywaniu nieśmiałości

16 M. McKay, M. Davis, P. Fanning, Sztuka skutecznego porozumierwania sie, przeł. A. Błaż, Gdańsk 2007, s. 40. 
i werbalizowaniu oczekiwań. W mniejszym stopniu wiązali otwartość z realizacją celów dydaktycznych.

Prawidłowa komunikacja powinna prowadzić do wzajemnego zrozumienia. Pozwala uświadomić sobie, co się dzieje między ludźmi i w jaki sposób mogą oni ze sobą wspólpracować. Zmusza to jednostkę do otwartości, czyli do gotowości na zmiany i przyjmowanie różnych punktów widzenia, co warunkuje konstruktywne dzielenie się informacjami. W tabeli 2 rozpatrzono sposób przekazywania informacji według opinii przyszłych nauczycieli języka angielskiego (grupa 1) i matematyki (grupa 2).

Tabela 2. Opinie studentów o sposobie przekazywania informacii

\begin{tabular}{|c|c|c|c|c|c|c|c|c|c|c|c|c|c|}
\hline \multirow{3}{*}{\multicolumn{2}{|c|}{ Przekaz informacji }} & \multicolumn{4}{|c|}{ inni nauczyciele } & \multicolumn{4}{|c|}{ uczeń } & \multicolumn{4}{|c|}{ klasa } \\
\hline & & \multicolumn{2}{|c|}{ tak } & \multicolumn{2}{|c|}{$\mathrm{Nie}$} & \multicolumn{2}{|c|}{ tak } & \multicolumn{2}{|c|}{ nie } & \multicolumn{2}{|c|}{ tak } & \multicolumn{2}{|c|}{ nie } \\
\hline & & $\mathrm{N}$ & $\%$ & $N$ & $\%$ & $N$ & $\%$ & $\mathrm{~N}$ & $\%$ & $\mathrm{~N}$ & $\%$ & $\mathrm{~N}$ & $\%$ \\
\hline \multirow{2}{*}{$\begin{array}{l}\text { Trzeba się zajqć } \\
\text { raczej osobq, niż jej } \\
\text { zachowaniem }\end{array}$} & Grupa 1 & 23 & 40,35 & 34 & 59,65 & 24 & 42,10 & 33 & 57,90 & 23 & 40,35 & 34 & 59,65 \\
\hline & Grupa 2 & 18 & 33,33 & 36 & 66,67 & 16 & 29,63 & 38 & 70,37 & 16 & 29,63 & 38 & 70,37 \\
\hline \multirow{2}{*}{$\begin{array}{l}\text { Trzeba przekazywać } \\
\text { wnioski, a nie } \\
\text { obserwacje }\end{array}$} & Grupa 1 & 25 & 43,86 & 32 & 56,14 & 29 & 50,88 & 28 & 49,12 & 28 & 49,12 & 29 & 50,88 \\
\hline & Grupa 2 & 20 & 37,04 & 34 & 62,96 & 32 & 59,26 & 22 & 40,74 & 34 & 62,96 & 20 & 37,04 \\
\hline \multirow{2}{*}{$\begin{array}{l}\text { Trzeba przekazywać } \\
\text { opis, a nie ocenę }\end{array}$} & Grupa 1 & 46 & 80,70 & 11 & 19,30 & 50 & 87,72 & 7 & 12,28 & 44 & 77,19 & 13 & 22,81 \\
\hline & Grupa 2 & 46 & 85,19 & 8 & 14,81 & 45 & 83,33 & 9 & 16,67 & 40 & 74,07 & 14 & 25,93 \\
\hline \multirow{2}{*}{$\begin{array}{l}\text { Trzeba się skupić na } \\
\text { „tu i teraz", a nie na } \\
\text { "gdzieś i kiedyś” }\end{array}$} & Grupa 1 & 45 & 78,95 & 12 & 21,05 & 45 & 78,95 & 12 & 21,05 & 46 & 80,70 & 11 & 19,30 \\
\hline & Grupa 2 & 40 & 74,07 & 14 & 25,93 & 42 & 77,78 & 12 & 22,22 & 40 & 74,07 & 14 & 25,93 \\
\hline \multirow{2}{*}{$\begin{array}{l}\text { Trzeba dzielić } \\
\text { się radq a nie } \\
\text { informacjami }\end{array}$} & Grupa 1 & 27 & 47,37 & 30 & 52,63 & 30 & 52,63 & 27 & 47,37 & 25 & 43,86 & 32 & 56,14 \\
\hline & Grupa 2 & 24 & 44,44 & 30 & 55,56 & 32 & 59,26 & 22 & 40,74 & 36 & 66,67 & 18 & 33,33 \\
\hline \multirow{2}{*}{$\begin{array}{l}\text { Trzeba myśleć } \\
\text { o tym, co zostało } \\
\text { powiedziane, a nie } \\
\text { o tym, dlaczego }\end{array}$} & Grupa 1 & 10 & 17,54 & 47 & 82,46 & 11 & 19,30 & 46 & 80,70 & 12 & 21,05 & 45 & 78,95 \\
\hline & Grupa 2 & 10 & 18,52 & 44 & 81,48 & 19 & 35,19 & 35 & 64,81 & 20 & 37,04 & 34 & 62,96 \\
\hline
\end{tabular}




\begin{tabular}{|c|c|c|c|c|c|c|c|c|c|c|c|c|c|}
\hline \multirow{3}{*}{\multicolumn{2}{|c|}{ Przekaz informacji }} & \multicolumn{4}{|c|}{ inni nauczyciele } & \multicolumn{4}{|c|}{ uczeń } & \multicolumn{4}{|c|}{ klasa } \\
\hline & & \multicolumn{2}{|c|}{ tak } & \multicolumn{2}{|c|}{ Nie } & \multicolumn{2}{|c|}{ tak } & \multicolumn{2}{|c|}{ nie } & \multicolumn{2}{|c|}{ tak } & \multicolumn{2}{|c|}{ nie } \\
\hline & & $N$ & $\%$ & $\mathrm{~N}$ & $\%$ & $N$ & $\%$ & $N$ & $\%$ & $\mathrm{~N}$ & $\%$ & $N$ & $\%$ \\
\hline \multirow{2}{*}{$\begin{array}{l}\text { Trzeba dawać tyle } \\
\text { informacji, ile tylko } \\
\text { można pomyśleć, } \\
\text { a nie tyle, ile } \\
\text { odbierający może } \\
\text { wykorzystać }\end{array}$} & Grupa 1 & 16 & 28,07 & 41 & 71,93 & 15 & 43,86 & 42 & 73,68 & 15 & 43,86 & 42 & 73,68 \\
\hline & Grupa 2 & 23 & 42,59 & 31 & 57,41 & 26 & 48,15 & 28 & 51,85 & 31 & 57,41 & 23 & 42,59 \\
\hline
\end{tabular}

W relacjach nauczyciel-uczeń przekazywanie informacji nie powinno budzić niepokoju ani wyzwalać reakcji obronnych. Sam sposób ich przekazywania może się przyczyniać do tworzenia atmosfery bezpieczeństwa. Zdecydowana większość przyszłych nauczycieli z obu grup (około 80\%) poprawnie wskazała, że należy się koncentrować na aktualnej sytuacji, zamiast na przeżyciach z przeszłości lub tych bliżej nieokreślonych.

Przekazywanie informacji to proces zdawania sprawy z przebiegu zdarzenia. Tak stwierdziło ponad trzy czwarte nauczycieli. Dla nich przekazywanie informacji zwrotnych powinno się wiązać z opisem sytuacji.

Udzielanie informacji winno się ograniczyć do takiej liczby, którą odbierający może spożytkować. Studenci matematyki częściej niż angliści wyrażali opinię, że jedną z zasad komunikowania powinno być dostosowanie przekazu do potrzeb odbiorcy. Nie zawsze nauczyciele zdają sobie sprawę, że nie wszystkie informacje można spożytkować, a czasem ich nadmiar może wręcz służyć wyłącznie zaspokojeniu potrzeb nadawcy.

Podstawą formułowania informacji powinny być zachowania, a nie wyobrażenia na temat drugiej osoby. Ważne jest, aby koncentrować się na tym, jak ktoś postępuje. Koncentracja na zachowaniach dominuje u badanych z grupy matematyki.

Opinie przyszłych nauczycieli dotyczące przekazywania swoich spostrzeżeń o zachowaniu, a nie dokonywanie ich interpretacji i osądów wykazują zróżnicowanie. Postawa wobec innych nauczycieli jest na ogół ujmowana prawidłowo, natomiast tendencja do oceniania jest nasilona w odniesieniu do ucznia i klasy. 
Korzystne jest koncentrowanie się tylko na treściach przekazywanych informacji, a nie dociekanie motywów ich wyrażania. Tylko niespełna 20\% badanych studentów rozumiało, że ważna jest treść wypowiedzi i sytuowano ją wśród zachować dostrzegalnych w stosunku do grona pedagogicznego. Szczególnie przyszli nauczyciele matematyki nieco korzystniej interpretowali takie podejście wobec ucznia i klasy. Pozostali prawdopodobnie zastanawialiby się dlaczego to zostało powiedziane. Taka wiedza i sposób rozumienia informacji pociągają za sobą ryzyko błędnej oceny osoby.

Około połowa badanych przejawia tendencję do udzielania rad, a nie dzielenia się informacjami. W ten sposób można jednak ograniczać wolność i odpowiedzialność innych osób oraz nie stwarzać właściwych sytuacji do uczenia się odpowiedzialności i ponoszenia konsekwencji podejmowanych działań. Jeśli zamiast udzielać gotowych rad przyszli nauczyciele dzieliliby się pomysłami rozwiązań i informacjami, pozwoliliby w ten sposób decydować uczniom o sobie. Zwłaszcza studenci anglistyki częściej skłonni byli do dzielenia się z radami z klasą. Być może dlatego, że wielu przyszłych nauczycieli jest zdania, iż posiada niezbędną wiedzę na temat skutecznych działań lub nieprawidłowo identyfikuje problemy uczniów, uznając je za własne i próbuje narzucić uczniom zmianę nastawienia do tego, co zrobili oraz do napotykanych trudności. Podejmują oni próbę rozwiązania problemów uczniów, stawiając jednocześnie przeszkodę blokująca wzajemne porozumienie. Takie zachowanie nauczyciela niesie ryzyko zmniejszenia poczucia kompetencji u ucznia i nie uczy odpowiedzialności za podejmowane działania ${ }^{17}$. „Dawanie (i odbieranie) informacji zwrotnych wymaga odwagi, umiejętności, zrozumienia i szacunku dla siebie i innych" ${ }^{18}$.

W sposobie przekazywania informacji zwrotnych ważne są zdaniem przyszłych nauczycieli aspekty niewerbalne, takie jak ton głosu, okazywanie zainteresowania, słuchanie, ale także właściwy dobór słów. Niektórzy badani wskazywali także na znaczenie aparycji nauczyciela. Przyszli matematycy podkreślali, że właściwe postępowanie nauczyciela może się przyczynić do kształtowania postawy

17 C.H. Edwards, Dyscyplina i kierowanie klasa, przeł. M. Bogdanowicz, Warszawa 2006, s. 205.

18 D.W. Johnson, Podaj dtoń, dz. cyt., s. 32. 
otwartości u uczniów, zaś niewłaściwe może ich blokować. Dialogowe porozumiewanie się w szkole ułatwia współdziałanie uczniów z nauczycielem i przyczynia się do osiągania sukcesów w nauce i budowania poczucia własnej wartości. Studenci filologii zwracali uwagę, że otwarte przekazywanie informacji zwrotnych wzbudza zaufanie, daje poczucie bezpieczeństwa, zachęca uczniów do kontaktów. Nauczyciel, który postępuje w taki sposób, „rozumie i widzi problemy swoich uczniów oraz próbuje je rozwiązać”, „uczniowie wiedzą, że mogą na niego liczyć”, „podchodzi indywidualnie do ich problemów". Przytoczone wypowiedzi studentów akcentują rolę nauczyciela w kształtowaniu rzeczywistego dialogu, opartego na szacunku i pozwalającego bez obaw wyrażać własne zdanie. Otwarty nauczyciel, zdaniem studentów, może się stać wzorem do naśladowania. Jednak należy uczulać przyszłych nauczycieli, że płaszczyzna otwartości powinna być kontrolowana i dopasowywana do konkretnych sytuacji, gdyż brak w tym obszarze oceniania i refleksyjności może prowadzić do chaotycznej otwartości nauczyciela, co nie będzie sprzyjało wzajemnym interakcjom, a może się stawać przyczyną doświadczania dyskomfortu i podejmowania ambiwalentnych zachowań, na co wskazują również wyniki badań Longiny Strumskiej-Cylwik ${ }^{19}$.

\section{Podsumowanie}

Otwartość jest traktowana w literaturze jako jeden z czterech ważnych obszarów kompetencji istotnych w porozumiewaniu się i tworzeniu przyjaznego środowiska - oprócz motywacji, czyli chęci skutecznego porozumiewania się, tolerancji dla tego, co nie jest jeszcze zapoznane, wiedzy i umiejętności nawiązywania relacji z innymi ${ }^{20}$.

Uzyskane wyniki badań pozwalają stwierdzić, że badani przyszli nauczyciele $\mathrm{w}$ większości prawidłowo rozumieją na czym polega otwartość. Badanym matematykom, w porównaniu do anglistów, rzadziej sprawiało trudności wiązanie wysyłanych komunikatów związanych z doświadczeniami z przeszłości i przekazywaniem informacji o własnych zachowaniach i odczuciach. W ważnym aspekcie, jakim

19 L. Strumska-Cylwik, Pomiędzy otwartościq i zamknięciem, dz. cyt., s. 343.

20 Por. R.B. Adler, L.B. Rosenfeld, R.F. Proctor II, Relacje interpersonalne. Proces porozumiewania się, przeł. G. Skoczylas, Poznań 2007. 
jest opis zachowań i własnych uczuć, co warunkuje tworzenie odpowiednich relacji, angliści rzadziej niż matematycy właściwie rozumieli istotę otwartości wobec ucznia i klasy. Ustosunkowując się do otwartości uczniów, studenci podkreślali, że jej poziom należy łączyć z wiekiem uczniów, specyficznymi cechami jednostki, a także z podmiotem interakcji. Przyszli nauczyciele pozytywnie oceniali otwartość uczniów, zauważając jej związek z efektywnym nauczaniem i sukcesami w nauce, przy czym częściej taką opinię wyrażali matematycy. Studenci anglistyki częściej natomiast podkreślali znaczenie otwartości w relacjach interpersonalnych, zarówno z nauczycielami, jak i z klasą, co dostrzegali również matematycy, lecz oni bardziej akcentowali jej rolę w osiąganiu dobrych wyników w nauce. Doceniane przez studentów dialogowe porozumiewanie się nauczyciela z uczniami eliminuje blokady komunikacyjne w przestrzeni edukacyjnej tylko wówczas, gdy przestrzegana jest reguła otwartości. W literaturze przedmiotu ${ }^{21}$ podkreśla się, że począwszy od siedemnastego roku życia wzrasta przeciętny poziom otwartości na innych.

Przyszli nauczyciele są świadomi, że poszerzanie własnej otwartości stwarza szanse na rozwój, ciekawe znajomości, doznania, eliminuje bariery między nadawcą i odbiorcą, ale przede wszystkim usuwa lęk przed nowymi doświadczeniami, dając poczucie bezpieczeństwa. Studenci matematyki częściej podkreślali, że liczbę przekazywanych informacji należy ograniczyć do tych, które uczniowie mogą wykorzystać. Informacje te powinny dotyczyć konkretnych zachowań, a nie ich interpretacji i oceny.

Badani odczuwali trudność w dostrzeganiu znaczenia koncentrowania się na treściach wypowiedzi. Przejawiali tendencję do dociekania motywów przekazywanych przez uczniów informacji, przy czym mieli z tym problem zazwyczaj angliści, a nie matematycy. Co drugi badany ma skłonność do udzielania rad uczniom i rozwiązywania ich problemów. Przyszli nauczyciele dostrzegali, że w przekazywaniu informacji ważne są także aspekty niewerbalne oraz podkreślali, że otwarte przekazywanie informacji zwrotnych wzbudza zaufanie i pomaga w budowaniu dobrych kontaktów z uczniem i klasą. Stereotypowa komunikacja w przestrzeni szkolnej, według badań Ewy

21 M. Davis, P. Fanning, M. McKay, Sztuka skutecznego porozumierwania się, dz. cyt., s. 40. 
Bochno ${ }^{22}$, budzi zastrzeżenia, gdyż sprzyja kształtowaniu u uczniów bierności, uległości i podporządkowania. W kierowaniu klasą i stymulowaniu procesu dydaktyczno-wychowawczego nauczyciel musi się stać partnerem w rozmowie, w czym na pewno pomaga umiejętne przekazywanie informacji zwrotnych ${ }^{23}$.

Umiejętność porozumiewania się obejmuje szereg kompetencji, które można nabyć w toku kształcenia uniwersyteckiego i odbywanych praktyk w edukacyjnej przestrzeni szkoły. Nauczyciel może stwarzać sytuacje, by pokazać jak od sposobu porozumiewania się zależy powodzenie w funkcjonowaniu społecznym i jakość interakcji $\mathrm{z}$ innymi ludźmi.

\section{Bibliografıa}

Adler R.B., Rosenfeld L.B., Proctor II R.F., Relacje interpersonalne. Proces porozumiewania się, przeł. G. Skoczylas, Dom Wydawniczy Rebis, Poznań 2007.

Bochno E., Rozmowa jako metoda oddziatywania wychowawczego, Oficyna Wydawnicza „Impuls”, Kraków 2004.

McKay M., Davis M., Fanning P., Sztuka skutecznego porozumiewania się, przeł. A. Błaż, Gdańskie Wydawnictwo Psychologiczne, Gdańsk 2007.

Edwards C.H., Dyscyplina i kierowanie klasa, przeł. M. Bogdanowicz, Wydawnictwo Naukowe PWN, Warszawa 2006.

Gołębniak B.D. Nabywanie kompetencji do refleksyjnego nauczania, w: Uczenie metoda projektów, red. B.D. Gołębniak, Wydawnictwa Szkolne i Profesjonalne, Warszawa 2002, s. 10-28.

Johnson D.W., Podaj dtoń, przeł. B. Czarnecka, Polskie Towarzystwo Psychologiczne, Warszawa 1992.

Kowalik S. (red.), Psychologia ucznia i nauczyciela, Wydawnictwo Naukowe PWN, Warszawa 2011.

Kwaśnica R., Dwie racjonalności. Od filozofii sensu ku pedagogice ogólnej, Wydawnictwo Naukowe Dolnośląskiej Szkoły Wyższej Edukacji TWP we Wrocławiu, Wrocław 2007.

Kwaśnica R., Wprowadzenie do myślenia o nauczycielu, w: Pedagogika, red. Z. Kwieciński, B. Śliwerski, Wydawnictwo Naukowe PWN, Warszawa 2006, s. 298-303.

22 E. Bochno, Rozmowa jako metoda oddziatywania wychowawczego, Kraków 2004.

23 S. Kowalik (red.), Psychologia ucznia i nauczyciela, Warszawa 2011. 
Kwiatkowska H., Pedeutologia, Wydawnictwa Akademickie i Profesjonalne, Warszawa 2008.

Mendel M., Przekraczanie progu szkoty jako „rite de passage”, w: Pedagogika miejsca, red. M. Mendel, Wydawnictwo Naukowe Dolnośląskiej Szkoły Wyższej Edukacji TWP we Wrocławiu, Wrocław 2006, s. 180-188.

Nalaskowski A., Przestrzenie i miejsca szkoty, Oficyna Wydawnicza „Impuls”, Kraków 2002.

Niebrzydowski L., Płaszczyński E., Przyjaźń i otwartość w stosunkach międzyludzkich, PWN, Warszawa 1989.

Strumska-Cylwik L., Pomiędzy otwartościq i zamknięciem, Oficyna Wydawnicza „Impuls”, Kraków 2005.

TuanY.-F., Przestrzeń i miejsce, przeł. A. Morawińska, Państwowy Instytut Wydawniczy, Warszawa 1987.

Wolicki M., Otwartość osoby ludzkiej. Interpretacja filozoficzna, Papieski Wydział Teologiczny we Wrocławiu, Wrocław 2005.

ADRES DO KORESPONDENCJI:

Dr Małgorzata Agnieszka Samujło

Uniwersytet Marii Curie-Skłodowskiej w Lublinie

Wydział Pedagogiki i Psychologii

Instytut Pedagogiki

e-mail: msamujlo@wp.pl

Doc. dr Teresa Sokołowska-Dzioba

Uniwersytet Marii Curie-Skłodowskiej w Lublinie

Wydział Pedagogiki i Psychologii

Instytut Pedagogiki

e-mail: edzioba@op.pl 